\title{
Lack of Evidence for the Drought-linked Chytridiomycosis Hypothesis
}

Kerry M. Kriger Centre for Innovative Conservation Strategies, School of Environment, Griffith University, Gold Coast, Queensland, Australia 9222 (email: kerry@savethefrogs.com)

ABSTRACT: A significant amount of recent research has focused on the potentially synergistic roles of climate change and disease in causing amphibian declines and extinctions. Herein I discuss the drought-linked chytridiomycosis hypothesis (DLCH), which states that prolonged or intensified dry seasons trigger or exacerbate epidemics of chytridiomycosis, a potentially lethal skin disease of amphibians caused by the chytrid fungus Batrachochytrium dendrobatidis. I demonstrate that the DLCH runs contrary to our knowledge of B. dendrobatidis physiology, biogeography, and hostparasite ecology and conclude that abnormally dry weather should actually favor amphibians by decreasing the prevalence, severity, and spread of chytridiomycosis.

Key words: Amphibian declines, Batrachochytrium dendrobatidis, climate change, extinction, global warming, wildlife disease.

Numerous hypotheses have been put forth to explain the rapid population declines that have affected amphibian species worldwide in recent decades. One explanation, the climate-linked epidemic hypothesis, has received increased attention in recent years (Pounds and Crump, 1994; Pounds et al., 1999; Kiesecker et al., 2001; Pounds, 2001; Harvell et al., 2002; Ron et al., 2003; Pounds and Puschendorf, 2004; Lampo et al., 2006; Pounds et al., 2006; Santiago-Paredes and La Marca, 2006; Alford et al., 2007; Bosch et al., 2007; Di Rosa et al., 2007; Pounds et al., 2007; Laurance, 2008; Lips et al., 2008). Although it is increasingly clear that various climate anomalies can alter the dynamics of host-pathogen systems (Harvell et al., 2002; Pounds et al., 2007), I suggest caution before accepting the hypothesis that prolonged or intensified dry seasons trigger or exacerbate epidemics of chytridiomycosis, a scenario hypothesized by several authors (Pounds et al.,
1999; Ron et al., 2003; Burrowes et al., 2004; Pounds and Puschendorf, 2004; Lampo et al., 2006; Santiago-Paredes and La Marca, 2006), but for which no empirical data exist. To distinguish this hypothesis from other climate-linked epidemic hypotheses, I will hereafter refer to it as the drought-linked chytridiomycosis hypothesis.

The drought-linked chytridiomycosis hypothesis proposes that abnormally dry conditions can exacerbate chytridiomycosis outbreaks by 1) increasing amphibian stress levels and subsequently decreasing immune function in infected or susceptible individuals (Lampo et al., 2006); 2) hindering the ability of infected amphibians to rehydrate sufficiently: Batrachochytrium dendrobatidis (the fungus that causes chytridiomycosis) affects the skin of the pelvic patch (Berger et al., 1998) and thus may significantly decrease an amphibians' water uptake during dry periods when water cannot be obtained directly from rainfall (Burrowes et al., 2004); and/ or 3) forcing amphibians to spend more time in a diminishing number of cool, moist hibernacula or breeding ponds, resulting in high densities of amphibians and thus optimal disease-transfer conditions (Pounds et al., 1999; Burrowes et al., 2004; Pounds and Puschendorf, 2004; Lampo et al., 2006). Although any of these mechanisms could conceivably result in the increased prevalence or severity of chytridiomycosis, the drought-linked chytridiomycosis hypothesis is inconsistent with our current knowledge of $B$. dendrobatidis physiology, biogeography, and host-parasite ecology. Below I discuss several reasons why abnormally dry periods should actually favor amphibians by 
decreasing the prevalence, severity, and spread of chytridiomycosis.

Batrachochytrium dendrobatidis has waterborne zoospores (Longcore et al., 1999; Piotrowski et al., 2004), and cannot survive desiccation (Johnson et al., 2003), so it is unlikely that that dry weather would benefit the fungus. Indeed, bioclimatic modeling predicts that the fungus is more likely to inhabit wetter regions (Ron, 2005), and recent field studies confirm this prediction. Kriger et al. (2007) found that both the prevalence and intensity of $B$. dendrobatidis infections in eastern Australia increase significantly in regions with high rainfall. Whereas chytrid infections were detected at all 17 sites that had received over $33 \mathrm{~mm}$ of rainfall in the 30 days prior to sampling, infections were detected at only half of the 14 sites that received less than $33 \mathrm{~mm}$ of rainfall. Kriger and Hero (2007a) demonstrated that $B$. dendrobatidis is largely restricted to wet microhabitats. Whereas $38.8 \%$ of 402 frogs breeding in permanent water bodies were infected with $B$. dendrobatidis, only one of 117 frogs breeding in ephemeral water bodies or in leaf litter was infected. Similarly, Longcore et al. (2007) found significantly higher infection prevalence $(22.9 \%, n=594)$ in amphibians utilizing aquatic hibernacula as compared to those utilizing terrestrial hibernacula $(8.3 \%, n=157)$. Infection prevalence in their study was significantly lower in 2001 than in 2000, and though daily mean temperatures did not differ significantly between the $2 \mathrm{yr}, 11$ of the 12 mo in 2001 were drier than their corresponding month in 2000. Finally, droughts often coincide with higher-than-average temperatures, and it is widely recognized that high temperatures are unfavorable to the growth and development of $B$. dendrobatidis (Piotrowski et al., 2004; Kriger and Hero, 2007b; Kriger et al., 2007).

Our knowledge of chytrid biology, detailed above, allows us to make important predictions regarding the influence of dry spells on chytridiomycosis host-para- site ecology. The first is that a significant proportion of a $B$. dendrobatidis population would likely be killed or be unable to reproduce during dry periods. Although dry conditions may increase amphibian stress levels, $B$. dendrobatidis would likely be unable to take advantage of the increased susceptibility of amphibians at these times, and thus we would expect decreases in the prevalence and intensity of chytrid infections during extended dry periods. The second prediction is that, as streams serve as likely vectors for the waterborne zoospores of $B$. dendrobatidis (Kriger and Hero, 2007a), a reduction in the number of flowing streams due to low rainfall would hinder the spread of the fungus. Further, if amphibians are forced to remain in hibernacula during dry periods, few individuals would be moving long distances, resulting in diminished opportunities for the chytrid fungus to be transferred between catchments or metapopulations (an important consideration when declines are concurrent with the apparent introduction of the fungus to a region (e.g., Lampo et al., 2006).

There exist no published studies that describe chytridiomycosis-linked mortality events concurrent with a reduction in either the available number of breeding ponds or the number of flowing streams. On the contrary, the vast majority of studies (Lips, 1998, 1999; Bosch et al., 2001; Muths et al., 2003; Lips et al., 2006; Rachowicz et al., 2006) detail mortality events occurring at permanent water bodies, and thus there is no reason to believe that chytridiomycosis epidemics are caused by an increase in the density of breeding aggregations due to abnormally dry weather. Although the number of ephemeral water bodies certainly decreases during dry spells, amphibians that breed in these habitats are at low risk of acquiring chytrid infections (Kriger and Hero, 2007a).

Batrachochytrium dendrobatidis has yet to be detected in amphibian retreat sites (Rowley et al., 2007). However, search 
effort has been low and it is certainly conceivable that amphibians may aggregate at hibernacula during dry periods and thus increase disease transmission. If this were the case, we would expect low detectability of amphibians during dry periods, because the amphibians would be hidden and inactive. Though 1987 and 1988 were the two driest of the $26 \mathrm{yr}$ examined by Lampo et al. (2006), these years had the third and fourth highest number of Atelopus collected, a result inconsistent with the hibernaculum hypothesis (it is also worth mentioning that neither chytrid nor population declines were detected in the 1987 dry year). Pounds and Crump (1994) concluded that Atelopus varius actually left their retreat sites en masse during the extreme dry periods of their study.

A strong association with aquatic habitats is a significant predictor of declining status in both Australian and Central American amphibians (Williams and Hero, 1998; Lips et al., 2003), with relatively few reports of declines in terrestrial breeding species, the ecologic guild most susceptible to desiccation, and least susceptible to chytrid infections (Lips, 1999; Lips et al., 2006; Kriger and Hero, 2007a). Thus, although it is plausible that $B$. dendrobatidis could act in conjunction with dry seasons to create a synergistic effect that results in high incidence of lethal desiccations and subsequent population decline, as hypothesized by Burrowes et al. (2004), this is unlikely to have contributed significantly to global amphibian declines. Interestingly, one of the few reported declines of a terrestrial breeding amphibian community occurred at La Selva, Costa Rica, where a significant increase in rainfall was recorded over the 35-yr study period (Whitfield et al., 2007). One of the few reports of declines in an ephemeral breeder (Bufo periglenes, also in Costa Rica) occurred during an abnormally dry year, yet had ecologic characteristics that the authors (Pounds and Crump, 1994) concluded were inconsistent with those of a decline caused by moisture stress.

Both climate anomalies (whether human induced or naturally occurring) and pathogens clearly contribute to global amphibian declines (Berger et al., 1998; Lips et al., 2006; Pounds et al., 2006; Rachowicz et al., 2006; Reading, 2007), and the interactions between the two remain largely unknown (Pounds et al., 2007). However, dry conditions are unlikely to favor $B$. dendrobatidis, and a great deal of empirically derived evidence will be required before researchers can add the drought-linked chytridiomycosis hypothesis to the list of valid mechanisms by which amphibian declines occur. Further, B. dendrobatidis, ranaviruses, and other amphibian pathogens are widespread (Green et al., 2002; Garner et al., 2005; Ouellet et al., 2005; Kriger et al., 2007). If enough climatic variables are examined and enough pathogens are sampled for, it is inevitable that researchers will occasionally detect some form of climate anomaly coincident with some form of infection at a site that has experienced amphibian decline. I suggest that in the absence of empirical data, researchers should be hesitant to conclude that a decline was caused or exacerbated by the synergism between a climate anomaly and pathogen unless the mechanism by which the decline likely occurred is in parallel with our current knowledge of the host-pathogen system in question.

I thank the Eppley Foundation for Research for providing financial support during the preparation of this manuscript. Maureen Donnelly, John Peterson, and Steven Whitfield provided valuable comments on an earlier version of this manuscript.

\section{LITERATURE CITED}

Alford, R. A., K. S. Bradfield, and S. J. Richards. 2007. Global warming and amphibian losses. Nature 447: E3-E4.

Berger, L., R. Speare, P. Daszak, D. E. Green, A. A. Cunningham, C. L. Goggin, R. Slocombe, M. A. Ragan, A. D. Hyatt, K. R. McDonald, H. B. 
Hines, K. R. Lips, G. Marantelli, and H. Parkes. 1998. Chytridiomycosis causes amphibian mortality associated with population declines in the rain forests of Australia and Central America. Proceedings of the National Academy of Sciences of the United States of America 95: 9031-9036.

Bosch, J., I. Martínez-Solano, and M. García-París. 2001. Evidence of a chytrid fungus infection involved in the decline of the common midwife toad (Alytes obstetricans) in protected areas of central Spain. Biological Conservation 97: 331337.

-, L. M. Carrascal, L. Duran, S. Walker, and M. C. Fisher. 2007. Climate change and outbreaks of amphibian chytridiomycosis in a montane area of Central Spain; is there a link? Proceedings of the Royal Society of London B Biological Sciences 274: 253-260.

Burrowes, P. A., R. L. Joglar, and D. E. Green. 2004. Potential causes for amphibian declines in Puerto Rico. Herpetologica 60: 141-154.

Di Rosa, I., F. Simoncelli, A. Fagotti, and R. Pascolini. 2007. The proximate cause of frog declines? Nature 447: E4-E5.

Garner, T. W. J., S. Walker, J. Bosch, A. D. Hyatt, A. A. Cunningham, and M. C. Fisher. 2005. Chytrid fungus in Europe. Emerging Infectious Diseases 11: 1639-1641.

Green, D. E., K. A. Converse, and A. K. Schrader. 2002. Epizootiology of sixty-four amphibian morbidity and mortality events in the USA, 1996-2001. Annals of the New York Academy of Sciences 969: 323-339.

Harvell, C. D., C. E. Mitchell, J. R. Ward, S. Altizer, A. P. Dobson, R. S. Ostfeld, and M. D. SAMuel. 2002. Climate warming and disease risks for terrestrial and marine biota. Science 296: 2158-2162.

Johnson, M., L. Berger, L. Phillips, and R. Speare. 2003. Fungicidal effects of chemical disinfectants, UV light, desiccation and heat on the amphibian chytrid, Batrachochytrium dendrobatidis. Diseases of Aquatic Organisms 57: 255260.

Kiesecker, J. M., A. R. Blaustein, and L. K. Belden. 2001. Complex causes of amphibian declines. Nature 410: 681-683.

Kriger, K. M., and J. M. Hero. 2007a. The chytrid fungus Batrachochytrium dendrobatidis is nonrandomly distributed across amphibian breeding habitats. Diversity and Distributions 13: 781788 .

2007b. Large-scale seasonal variation in the prevalence and severity of chytridiomycosis. Journal of Zoology 271: 352359.

-, F. Pereoglou, and J. M. Hero. 2007. Latitudinal variation in the prevalence and intensity of chytrid (Batrachochytrium dendro- batidis) infection in eastern Australia. Conservation Biology 21: 1280-1290.

Lampo, M., A. Rodríguez-Contreras, E. La Marca, AND P. DASZAK. 2006. A chytridiomycosis epidemic and a severe dry season precede the disappearance of Atelopus species from the Venezuelan Andes. Herpetological Journal 16: 395-402.

Laurance, W. F. 2008. Global warming and amphibian extinctions in eastern Australia. Austral Ecology 33: 1-9.

LIPS, K. R. 1998. Decline of a tropical montane amphibian fauna. Conservation Biology 12: 106117.

1999. Mass mortality and population declines of anurans at an upland site in western Panama. Conservation Biology 13: 117-125.

, J. D. Reeve, and L. R. Witters. 2003. Ecological traits predicting amphibian population declines in Central America. Conservation Biology 17: 1078-1088.

—, F. Brem, R. Brenes, J. D. Reeve, R. A. Alford, J. Voyles, C. Carey, L. Livo, A. P. Pessier, and J. P. Collins. 2006. Emerging infectious disease and the loss of biodiversity in a neotropical amphibian community. Proceedings of the National Academy of Sciences of the United States of America 103: 3165-3170.

- J. Diffendorfer, J. R. Mendelson, III, And M. W. SEars. 2008. Riding the wave: Reconciling the roles of disease and climate change in amphibian declines. PLoS Biology 6: 441-454.

Longcore, J. E., A. P. Pessier, and D. K. Nichols. 1999. Batrachochytrium dendrobatidis gen. et sp. nov., a chytrid pathogenic to amphibians. Mycologia 91: 219-227.

Longcore, J. R., J. E. Longcore, A. P. Pessier, and W. A. Halteman. 2007. Chytridiomycosis widespread in anurans of northeastern United States. Journal of Wildlife Management 71: 435-444.

Muths, E., P. S. Corn, A. P. Pessier, and D. E. Green. 2003. Evidence for disease related amphibian decline in Colorado. Biological Conservation 110: 357-365.

Ouellet, M., I. Mikaelian, B. D. Pauli, J. Rodrigue, And D. M. Green. 2005. Historical evidence for widespread chytrid infection in North American amphibian populations. Conservation Biology 19: 1431-1440.

Piotrowski, J. S., S. L. Annis, and J. E. Longcore. 2004. Physiology of Batrachochytrium dendrobatidis, a chytrid pathogen of amphibians. Mycologia 96: 9-15.

Pounds, J. A. 2001. Climate and amphibian declines. Nature 410: 639-640.

-, and M. L. Crump. 1994. Amphibian declines and climate disturbance: The case of the golden toad and the harlequin frog. Conservation Biology 8: 72-85. 
and R. Puschendorf. 2004. Clouded futures. Nature 427: 107-109.

-, M. P. L. Fogden, and J. H. Campbell. 1999. Biological response to climate change on a tropical mountain. Nature 398: 611-615.

-, M. R. Bustamante, L. A. Coloma, J. A. Consuegra, M. P. L. Fogden, P. N. Foster, E. La Marca, K. L. Masters, A. Merino-Viteri, R. Puschendorf, S. R. Ron, G. A. SAnchezAzofeifa, C. J. Still, and B. E. Young. 2006. Widespread amphibian extinctions from epidemic disease driven by global warming. Nature 439: 161-167.

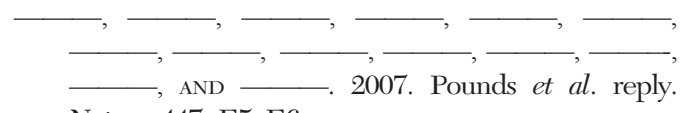
Nature 447: E5-E6.

Rachowicz, L. J., R. A. Knapp, J. A. T. Morgan, M. J. Stice, V. T. Vredenburg, J. M. Parker, and C. J. Briggs. 2006. Emerging infectious disease as a proximate cause of amphibian mass mortality. Ecology 87: 1671-1683.

Reading, C. J. 2007. Linking global warming to amphibian declines through its effects on female body condition and survivorship. Oecologia 151: 125-131.

Ron, S. R. 2005. Predicting the distribution of the amphibian pathogen Batrachochytrium dendrobatidis in the new world. Biotropica 37: 209-221.
W. E. Duellman, L. A. Coloma, and M. R. Bustamante. 2003. Population decline of the Jambato Toad Atelopus ignescens (Anura, Bufonidae) in the Andes of Ecuador. Journal of Herpetology 37: 117-126.

Rowley, J. L., L. F. Skeratt, R. A. Alford, and R. Campbell. 2007. Retreat sites of rain forest stream frogs are not a reservoir for Batrachochytrium dendrobatidis in northern Queensland, Australia. Diseases of Aquatic Organisms 74: 7 12.

Santiago-Paredes, S., and E. La Marca. 2006. Comportamiento del clima a finales del siglo $\mathrm{XX}$ en los altos Andes Venezolanos y el declive de Atelopus mucubajiensis. Herpetotropicos 3: $7-20$.

Whitfield, S. M., K. E. Bell, T. Philippi, M. SAsa, F. Bolanos, G. Chaves, J. M. Savage, and M. A. Donnelly. 2007. Amphibian and reptile declines over 35 years at La Selva, Costa Rica. Proceedings of the National Academy of Sciences of the United States of America 104: 8352-8356.

Williams, S. E., and J. M. Hero. 1998. Rainforest frogs of the Australian Wet Tropics: Guild classification and the ecological similarity of declining species. Proceedings of the Royal Society of London 265: 597-602.

Received for publication 1 April 2008. 